\title{
Study on Stipend Program and Girls' Education in Public Schools of Sindh
}

\section{Muhammad Safar Unar, Tayyaba Zarif* \\ Aziz-Un-Nisa**}

\begin{abstract}
Women empowerment through education process is the key element for the national development by providing basic resources \& facilities. Every country has taken systemic initiatives for the development of girls' education at all levels, to empower women, Pakistan has also started number of motivational steps for girls' education especially in Sindh. Consequently government of Sindh has taken numerous initiatives to promote girls' education, in this connection girls' stipend program started was from 2001 for girls' students studying from VI to X level in public schools of Sindh. Keeping in view, the primary purpose of this study was to know the effectiveness of girls' stipend program in public schools of Sindh on the enrollment, attendance of girls, encouragement of parents' motivational \& interest level of parents' towards continuity of education process as per the perception of head teachers . Current study was descriptive in nature and quantitative by method. Population of this study was all head teachers of elementary, middle and secondary schools of Sindh. Targeted population of this study was all head teachers of elementary, middle and secondary schools of district Shaheed Benazir Abad. Seventy percent head teachers of elementary,
\end{abstract}


middle and secondary schools was selected by convenient random sampling from the targeted population of the study. Questionnaire with five points Likert scale was developed for exploring the perception of head teachers' about effectiveness of girls' stipend program. Data was analyzed by the help of percentage. Findings of this study identified that girls' stipend program proved as motivational factor for the enrolment, attendance, continuity and encouragement of parents and for girls who were studying in $6^{\text {th }}$ to $10^{\text {th }}$ classes in public schools.

Key Words: Effectiveness, Girls' Stipend Program, education process, perception, head teachers

* Shaheed Benazir Bhutto University, Shaheed Benazir Abad

** Assistant Professor, Department of Education, University of Karachi 


\section{Introduction}

The population of Pakistan consists of $52 \%$ on female gender. So it is very important to educate female to make nation stable, developed and successful country in the world. Government of Pakistan is facing the problem of low rate of girls' education since many years. Mostly in all developing countries, secondary school enrolment lowers for female than male, especially in remote areas (Shahdur, 2003) Main center of literacy programmers in Pakistan was on the girls' population. More than $80 \%$ of literacy centers were for female. A number of improvement programs and project have been launched since 2000 for the encouragement of girls' primary education and female literacy. These projects and program were starting to show optimistic consequences,(GoVand MoE, 2008). In every province, girls' education remained big challenge, and so many initiatives were being taken by provinces such as free text book, free and quality education for remote areas by the collaboration of Sindh education foundation, and girls' stipend program in all public school of Sindh.

The education is key factor for a successful nation and all the progress, development and sustainability depends upon quality of education. Education enhances the status of human being and guides everyone to prosperity and liberty, because of that our great leader and founder of Pakistan Quaid-e-Aazam Muhammad Ali Jinnah laid stress on getting education. Once, he said to the students in his speech that "Education is a matter of life and death for our country" and Robert may nard Hutchins said about education as "The object of education is to prepare the young to educate themselves throughout their lives" and on another place Edward Everett describes that "Education is a better safeguard of liberty than a standing army". Education turns huge population into productive human resource. Education is the initial element for everyone, male as well as female equally. Every Pakistani citizen has right to get education according the constitution of Pakistan, as the article 25-A constitution of Pakistan states that "The state shall provide free and compulsory education to all children of the age five to sixteen years in such a manner as may be determined by the law" and before the $18^{\text {th }}$ amendment of constitution , Pakistan's education system was the responsibility of federal government and ministry of education at federal level was the responsible for the planning, formulating policies and promotion of educational facilities in the country, but after the $18^{\text {th }}$ amendment the responsibilities of education system were divided 
among provinces and federation level. As Pakistan consists of four provinces namely Sindh, Punjab, Baluchistan and Khyber Pakhutun KhuwahA. K. Pakistan (2015)every province is trying to improve its educational ratio, for that Government of Sindh has initiated many positive steps to improve the educational ratio in both rural and urban areas. According to the web site of Sindh education that government of Sindh also started many reforms programs to enhance the enrollment, such as free text book, free education for all at door step by private partnership (PPRS, ILEP) with the collaboration of Sindh education foundation scholarships in higher education and stipend program for female students in all public schools. Government of Sindh has started education reform program to deal the issues of quality, governance and access of education.

The Girls' stipend program is the one part of this program. Girls' stipend program introduced from 2001 due to low enrolment in classes from VI TO X in all public schools of Sindh government according the website of Sindh.As Sindh government started girls' stipend program from 2001-2002 academic years as motivational factors to enhance enrollment and reduce the drop out ratio in secondary education and still it is supporting to all those girls who are studying in class $6^{\text {th }}$ to $10^{\text {th }}$ in public schools of Sindh. This research study intended to explore the perception of Head teachers on: Enrollment, Attendance of, and Interest level, Encouragement of parents, Motivational level of girls' students and parents and Continuity of girls' education from classes VI to X.

\subsection{Objectives of Study}

1. To study the impact/ effectiveness of Girls stipend program on enrollment of girls' students in public schools as per the perception of head teachers

2. To measure the satisfaction of head teachers with the attendance of girls' students in classes $6^{\text {th }}$ to $10^{\text {th }}$ due to girls' stipend program?

3. To study the interest level of girls' students increased due to the girls' stipend program?

4. To assess the Head teachers' perceptions that motivational level \& encouragement of girls and their parents enhanced due to girls stipend program?

5. To study the head teachers satisfaction on the continuity of girls' education in classes $6^{\text {th }}, 7$ th, 8 th, 9 th and $10^{\text {th }}$ due to the girls' stipend program? 


\subsection{Research Qestions}

1. What is impact /effectiveness of Girls stipend program on enrollment of girls' students in public schools as per the perception of head teachers?

2. To what extent the Head teachers are satisfied with the attendance of girls' students in classes $6^{\text {th }}$ to $10^{\text {th }}$ due to girls' stipend program?

3. To what extent the interest level of girls' students increased due to the girls' stipend program?

4. To what extent the Head teachers' percept that motivational level \& encouragement of girls and their parents enhanced due to girls stipend program?

5. Do the head teachers satisfy on the continuity of girls' education in classes $6^{\text {th }}, 7$ th, 8 th, 9 th and $10^{\text {th }}$ due to the girls' stipend program?

\section{Litrature Review}

One of the first attempts in the field of education and literacy was the National Education Conference in 1947. The Quaid-e-Azam, in his message to the Conferences said:

"... The importance of education and the type of education cannot be overemphasized ... There is no doubt that the future of our State will and must greatly depend upon the type of education we give to our children, and the way in which we bring them up as future citizens of Pakistan ...We should not forget that we have to compete with the world which is moving very fast in this direction." (Bilqees 2004 and GoV and MoE 2008).At the Rio conference, which was held in 2012 in Brazil, the United Nations announced that the education gap to be a main difference urbanized and developing countries. World Bank evaluation 2005 has recognized the government's education policy to be broad but very motivated and in front of the capability of the Ministry of Education(Bank 2005 and Chadzuka 2008). UNICEF works with the Pakistan Government to support the education sector at all levels. This includes providing technical support such as research, planning, monitoring and policy formulation, particularly to establish alternative education pathways for the most marginalized children(Kearney 2015). Herz (1991)and Sperling (2004)stated that, according the World Bank a study of hundred countries described that rising the share of female who have a secondary education by 1 per cent boosts once a year for every capita income with 0.3 per cent. According the Herz and Mannan and Webpage (2019)Girls' 
education may bear from the higher expenses of educating girls than boys in many developing countries. Dollar (1999) discover that female education, particularly at the secondary level, is the cause of economic increase. In favor of Tajikistan, the Bank (2005) has recognized gender equity and equality as a critical trouble, but has argued for attempt common education issues, failing to intend policies particularly expected at reducing the gap in girls' education; it cites the small quantity of funds as a main restraint. An investigation with both house circle- and school-level data shows that the national rural stipend program for girls has had an important encouraging impact and fruitful factor on the secondary school in Bangladesh (Shahdur, R., 2003).This positive development has occurred due to some specific public interventions focusing on girl students, such as stipends and exemption of tuition fees for girls in rural areas and the stipend scheme for girls at the secondary level. Bangladesh has made significant progress in promoting the objectives of ensuring gender equality and empowerment of women (MDG 2012). In many developing countries scholarships have been key role in raising the school enrolment. Every country have presented diversity of these type of scheme for both genders at different levels. Though, stipend program particularly introduced to promote girls enrolment in limited districts of Pakistan and Bangladesh where the enrolment ratio given continuously less as well as retention in educational institution as compared to boys. The study also highlighted the impact of stipend to families with the help of girls respect and consent in the community. It was defined by the respondents that this has affected some and societies also initiated to change their behavior. The current research also indicated the issues of late payment of stipend, which have badly affected the girls' enrolment, causing no modification either in school or at home. Some girls have shown signs to build confidence. In those areas where the stipend broadly went late, girls including their parents found chaotic regarding the scheme of stipend as well as its benefits (Hussain, S., 2016 and Jafred 2018). Educating girls and young women is an important development objective, reflected, for example, in the United Nations Millennium Development Goals. Motivated by the potential long-term benefits of improving education levels, a number of developing countries have abolished school tuition fees, experimented with compulsory education laws and/or introduced stipend programs designed to increase educational attainment, particularly for girls (Bilqees 2004; Hahna 2015 and Naveed, 2018) Many researchers conducted researches on the stipend program in Pakistan, Bangladesh and in many other countries of the world but in Sindh particularly in district Shaheed Benazir Abad no any research conducted on the stipend program, so it will be first research on the 
effectiveness of stipend program in Sindh. It is justified by donating agencies that by providing stipend and financial assistance as a tool for raising the enrolment and to retain the girls in school, instead of simply increasing the entrance as well as decreasing discrimination of sex in current secondary schools (Simeen, 2003; Smyth 2012).

\section{Research Methodology}

The research design of this study was quantitative by method and descriptive by purpose.

As the population of this study was all Head teachers of Government girls and mix secondary, middle and elementary schools of Sindh, in which girls' students of class $6^{\text {th }}, 7$ th, 8 th, 9 th and $10^{\text {th }}$ were enrolled. In S.B.A district the numbers of schools were 69, 55 and 48 secondary, middle and elementary respectively. District Shaheed Benazir Abad had four Talukas namely: Nawab shah, Sakrand, Kazi Ahmed and Dour. Researcher selected $80 \%$ of the total girls and mixed elementary, middle and secondary schools of district Shaheed Benazir Abad through non probability (convenient) sampling technique. The researchers used closed ended questionnaire for the respondents (which were Head teachers), which was consist on five point Likert scale including strongly disagree, disagree, undecided, agree and strongly agree. Collected data was analyzed with the help of MS excel and MS word in the form of tables and percentages.

\section{Data Analysis And Interpretation}

The research study was based on five research questions which were focused on five main themes like, girls' stipend program and enrolment of girls' students, stipend program and progression in the girls attendance from class 6 to 10, stipend program and interest level of girls students towards schooling motivational level and encouragement of girls and their parents, and stipend program and retention of girls from class 6 to 10.The analysis of these themes actually interpret the effectiveness of girls' stipend program, according to the perception of head teachers of public sector schools stipend program according to above themes as per the perception of head teachers of public sector schools as under. 
Analysis of Theme No One : Stipend program and enrolment of girls' students

\begin{tabular}{|l|l|l|l|l|l|l|}
\hline Items & $\begin{array}{l}\text { Strongly } \\
\text { disagree }\end{array}$ & Disagree & Undecided & Agree & $\begin{array}{l}\text { Strongly } \\
\text { agree }\end{array}$ & Total \\
\hline 1 & $2 \%$ & $3 \%$ & $9 \%$ & $67 \%$ & $19 \%$ & $100 \%$ \\
\hline 2 & $2 \%$ & $4 \%$ & $3 \%$ & $62 \%$ & $29 \%$ & $100 \%$ \\
\hline 3 & $1 \%$ & $8 \%$ & $16 \%$ & $53 \%$ & $22 \%$ & $100 \%$ \\
\hline 4 & $9 \%$ & $6 \%$ & $40 \%$ & $33 \%$ & $12 \%$ & $100 \%$ \\
\hline $\begin{array}{l}\text { Aggregate } \\
\text { percent }\end{array}$ & $4 \%$ & $5 \%$ & $17 \%$ & $54 \%$ & $21 \%$ & $100 \%$ \\
\hline
\end{tabular}

The results regarding the research question which was regarding Impact/effectiveness of Girls stipend program on enrollment of girls' students which encompassed the Increase in class six after 2001, Encouraged the objectives of improving quality and enrollment increase in rural areas. The results depict that $4 \%$ of the respondents strongly disagreed, $5 \%$ of the respondents disagreed $17 \%$ of the respondents remained undecided, whereas $54 \%$ of the respondents agreed and $21 \%$ of the respondents strongly agreed with above areas. The results suggest that the majority of the respondents agreed that the stipend program benefited in increase in enrolment, quality education and as an encouragement for the parents of the girls' students.

Analysis of Theme No Two : Stipend Program and progression in the girls attendance from class 6 to 10

\begin{tabular}{|l|l|l|l|l|l|l|}
\hline Item no & $\begin{array}{l}\text { Strongly } \\
\text { disagree }\end{array}$ & disagree & Undecided & agree & $\begin{array}{l}\text { Strongly } \\
\text { agree }\end{array}$ & Total \\
\hline 5 & $0 \%$ & $5 \%$ & $0 \%$ & $68 \%$ & $27 \%$ & $100 \%$ \\
\hline 6 & $6 \%$ & $71 \%$ & $3 \%$ & $12 \%$ & $9 \%$ & $100 \%$ \\
\hline 7 & $5 \%$ & $3 \%$ & $5 \%$ & $61 \%$ & $25 \%$ & $100 \%$ \\
\hline 8 & $28 \%$ & $32 \%$ & $8 \%$ & $23 \%$ & $9 \%$ & $100 \%$ \\
\hline $\begin{array}{l}\text { Aggregate } \\
\text { percentage }\end{array}$ & $10 \%$ & $28 \%$ & $4 \%$ & $40 \%$ & $18 \%$ & $100 \%$ \\
\hline
\end{tabular}

The results regarding the research question which was regarding Head teachers' satisfaction with the attendance of girls' students in classes $6^{\text {th }}$ to $10^{\text {th }}$, which encompassed Decreased absenteeism, Increase attendance above 
$80 \%$ parental interest in school students. The results depict that $10 \%$ of the respondents strongly disagreed, $28 \%$ of the respondents disagreed $4 \%$ of the respondents remained undecided, whereas $40 \%$ of the respondents agreed and $18 \%$ of the respondents strongly agreed with above areas. The results suggest that the majority of the respondents agreed that the stipend program benefited in decreasing absenteeism, increasing attendance above eighty percent and parental interest in schools.

\section{Research question No: Three : Stipend Program \& Interest level of girls students towards Schooling}

\begin{tabular}{|l|l|l|l|l|l|l|}
\hline Item no & $\begin{array}{l}\text { Strongly } \\
\text { disagree }\end{array}$ & Disagree & Undecided & Agree & $\begin{array}{l}\text { Strongly } \\
\text { agree }\end{array}$ & Total \\
\hline 9 & $0 \%$ & $7 \%$ & $2 \%$ & $66 \%$ & $26 \%$ & $100 \%$ \\
\hline 10 & $1 \%$ & $7 \%$ & $1 \%$ & $62 \%$ & $29 \%$ & $100 \%$ \\
\hline 11 & $1 \%$ & $15 \%$ & $6 \%$ & $63 \%$ & $16 \%$ & $100 \%$ \\
\hline $\begin{array}{l}\text { Aggregate } \\
\text { percentage }\end{array}$ & $1 \%$ & $5 \%$ & $3 \%$ & $67 \%$ & $24 \%$ & $100 \%$ \\
\hline
\end{tabular}

The results regarding the research question which was regarding Head teachers' satisfaction with the increase in interest level of girls' students in classes $6^{\text {th }}$ to $10^{\text {th }}$, which encompassed, girls' enhancement in interest level, served as a motivational factor and increase in admission on yearly basis. The results depict that $1 \%$ of the respondents strongly disagreed, $5 \%$ of the respondents disagreed $3 \%$ of the respondents remained undecided, whereas $67 \%$ of the respondents agreed and $24 \%$ of the respondents strongly agreed with above areas. The results suggest that a huge majority of the respondents agreed that the stipend program benefited in enhancement in girls interest level, served as a motivational factor and increase in admission on yearly basis.

\section{Analysis of Theme No Four : Motivational level \& Encouragement of girls and their parents}

\begin{tabular}{|l|l|l|l|l|l|l|}
\hline Item no & $\begin{array}{l}\text { Strongly } \\
\text { disagree }\end{array}$ & disagree & undecided & agree & $\begin{array}{l}\text { Strongly } \\
\text { agree }\end{array}$ & Total \\
\hline 12 & $1 \%$ & $6 \%$ & $2 \%$ & $53 \%$ & $38 \%$ & $100 \%$ \\
\hline
\end{tabular}




\begin{tabular}{|l|l|l|l|l|l|l|}
\hline 13 & $9 \%$ & $26 \%$ & $5 \%$ & $34 \%$ & $26 \%$ & $100 \%$ \\
\hline 14 & $29 \%$ & $25 \%$ & $3 \%$ & $38 \%$ & $4 \%$ & $100 \%$ \\
\hline 15 & $2 \%$ & $6 \%$ & $9 \%$ & $74 \%$ & $9 \%$ & $100 \%$ \\
\hline 16 & $2 \%$ & $10 \%$ & $6 \%$ & $56 \%$ & $26 \%$ & $100 \%$ \\
\hline 17 & $3 \%$ & $18 \%$ & $7 \%$ & $54 \%$ & $17 \%$ & $100 \%$ \\
\hline 18 & $6 \%$ & $19 \%$ & $32 \%$ & $30 \%$ & $13 \%$ & $100 \%$ \\
\hline 19 & $19 \%$ & $39 \%$ & $10 \%$ & $26 \%$ & $6 \%$ & $100 \%$ \\
\hline 20 & $11 \%$ & $12 \%$ & $9 \%$ & $55 \%$ & $12 \%$ & $100 \%$ \\
\hline $\begin{array}{l}\text { Aggregate } \\
\text { percentage }\end{array}$ & $9 \%$ & $17.9 \%$ & $9.25 \%$ & $46.67 \%$ & $16.78 \%$ & $100 \%$ \\
\hline
\end{tabular}

The results regarding the research question which was regarding Head teachers' perceptions about enhancement of motivational level \& encouragement of girls and their parents, which encompassed, Continuity of girl's education, satisfaction with transparency of stipend, parental interest in educational matters, quality of girls education, reduction in gender disparity easement in stipend distribution, stipend as a basic financial basic need and awareness for girls education. The results depict that $9 \%$ of the respondents strongly disagreed, $18 \%$ of the respondents disagreed $10 \%$ of the respondents remained undecided, whereas $47 \%$ of the respondents agreed and $17 \%$ of the respondents strongly agreed with above areas. The results suggest that a bigger majority of the respondents agreed that the stipend program benefited in Continuity of girl's education, satisfaction with transparency of stipend, parental interest in educational matters, quality of girls education, reduction in gender disparity easement in stipend distribution, stipend as a basic financial basic need and awareness for girls education.

Analysis of theme No Five : Stipend program and retention of girls from class 6 to 10 .

\begin{tabular}{|l|l|l|l|l|l|l|}
\hline Item no & $\begin{array}{l}\text { Strongly } \\
\text { disagree }\end{array}$ & Disagree & undecided & agree & $\begin{array}{l}\text { Strongly } \\
\text { agree }\end{array}$ & Total \\
\hline 21 & $0 \%$ & $18 \%$ & $5 \%$ & $65 \%$ & $12 \%$ & $100 \%$ \\
\hline 22 & $0 \%$ & $3 \%$ & $6 \%$ & $70 \%$ & $21 \%$ & $100 \%$ \\
\hline 23 & $3 \%$ & $4 \%$ & $10 \%$ & $42 \%$ & $41 \%$ & $100 \%$ \\
\hline 24 & $1 \%$ & $10 \%$ & $4 \%$ & $62 \%$ & $22 \%$ & $100 \%$ \\
\hline 25 & $4 \%$ & $6 \%$ & $9 \%$ & $68 \%$ & $13 \%$ & $100 \%$ \\
\hline 26 & $3 \%$ & $46 \%$ & $10 \%$ & $34 \%$ & $6 \%$ & $100 \%$ \\
\hline
\end{tabular}


Study on Stipend Program and Girls' Education in Public Schools of Sindh

\begin{tabular}{|l|l|l|l|l|l|l|}
\hline $\begin{array}{l}\text { Aggregate } \\
\text { percentage }\end{array}$ & $2 \%$ & $15 \%$ & $7 \%$ & $57 \%$ & $19 \%$ & $100 \%$ \\
\hline
\end{tabular}

The results regarding the research question which was regarding Head teachers satisfaction on the continuity of girls' education in classes $6^{\text {th }}, 7$ th, 8th, 9th and10 th, which encompassed, increase in enrolment in rural areas, decrease in drop out of girls students, regularity and punctuality in their classes. The results depict that $2 \%$ of the respondents strongly disagreed, $15 \%$ of the respondents disagreed $7 \%$ of the respondents remained undecided, whereas $57 \%$ of the respondents agreed and $19 \%$ of the respondents strongly agreed with above areas. The results suggest that a bigger majority of the respondents agreed that the stipend program benefited in increase in enrolment in rural areas, decrease in drop out of girls students, regularity and punctuality in their classes for girls education.

\section{Findings Of The Study}

The findings of the research study on the basis of data analysis suggest that, the results regarding the research question one which was regarding Impact /effectiveness of Girls stipend program on enrollment of girls' students which encompassed the increase in class six after 2001, encouraged the stud3ents, improving quality and enrollment increase in rural areas. The results suggest that the majority of the respondents agreed that the stipend program benefited in increase in enrolment, quality education and as an encouragement for the parents of the girls' students of public schools.

The results regarding the research question two which was regarding Head teachers' satisfaction with the attendance of girls' students in classes $6^{\text {th }}$ to $10^{\text {th }}$, which encompassed decrease in absenteeism, increase attendance above $80 \%$, parental interest in school of their children. The results depicted that the majority of the respondents agreed that the stipend program benefited in decreasing absenteeism, increasing attendance above eighty percent and parental interest in schools, whereas a least number of the respondents either disagreed or remained undecided.

The results regarding the research question number three, which was regarding Head teachers' satisfaction with the increase in interest level of girls' students in classes $6^{\text {th }}$ to $10^{\text {th }}$, which encompassed, girls' enhancement in interest level, served as a motivational factor and increase in admission on yearly basis. The results suggest that a huge majority of the respondents 
agreed that the stipend program benefited in enhancement in girls' interest level, served as a motivational factor and increase in admission on yearly basis, where as a least number of the respondents disagreed with the above areas.

The results regarding the research question number four, which was regarding Head teachers' perceptions about enhancement of motivational level \& encouragement of girls and their parents, which encompassed, Continuity of girl's education, satisfaction with transparency of stipend, parental interest in educational matters, quality of girls education, reduction in gender disparity easement in stipend distribution, stipend as a basic financial basic need and awareness for girls education. The results suggest that a bigger majority of the respondents agreed that the stipend program benefited in Continuity of girl's education, satisfaction with transparency of stipend, parental interest in educational matters, quality of girls education, reduction in gender disparity easement in stipend distribution, stipend as a basic financial basic need and awareness for girls education. The results regarding the research question five which was regarding Head teachers satisfaction on the continuity of girls' education in classes $6^{\text {th }}, 7$ th, 8th, 9th and $10^{\text {th }}$, which encompassed, increase in enrolment in rural areas, decrease in drop out of girls students, regularity and punctuality in their classes. The results suggest that a bigger majority of the respondents agreed that the stipend program benefited in increase in enrolment in rural areas, decrease in drop out of girls students, regularity and punctuality in their classes for girls education.

\section{Discussion}

The results of the current study in the area of enrollment of girl students increased due to stipend program in secondary level education are very resembling withYoujin Hahna (2015), who had conducted same type of research in Bangladesh in 2003, And Doller (1999) also resembled the same results about female education increased due to financial support. The results of the current study in the area of attendance of girls students increased because of stipend program are resemble with Sperling., (2004), who had conducted same type of research in New York in 2004.

\section{Conclusion}

Analyzed results concluded that girl's stipend program improved the enrollment of girls' students in secondary education in public school and attendance of students remained above than $80 \%$ as per requirement of girls' 
stipend program (Sperling., 2004). Findings of this study showed that interest level and motivational level of girls' students and their parents enhanced due to the stipend program, encouragement of parents to allow their daughters for study also increased after girls' stipend program. Due to the stipend amount girls' students continued their study and mostly girls' students completed their secondary education, in this way; drop out ratio decreased from the secondary education for girls' students studying in class 6 th to $10^{\text {th }}$ in public schools. Finally it was concluded that girls' stipend program motivated girls' students and their parents to continue their studies, it maintained the transparency in disbursement of stipend amount. Girls students fulfilled their financial needs by annual stipend amount, in this way; dropout ratio decreased from secondary education.

\section{Recommendation}

On the basis of findings of this research work, there are some suggestions to increase enrolment rate of girls' students from primary education to secondary education in public schools of Sindh

01- On need basis, girls' stipend amount should be increased and provided stipend amount in the starting of the academic year

02- Teaching staff and non- teaching staff of girls' schools should be female and provide facilities of free pick and drop to all enrolled girls students in public schools, specially where there is no such facility and access.

03- Provide basic facilities in girls' public schools such as furniture, drinking water, electricity, toilets and play ground.

04- Along with stipend amount government should support the poor girls' students with additional facilities like stationary, shoes, uniform and registers. 
Jhss, Vol. 7, No. 1 , January to June, 2016

05- Stipend amount should be increased and delivered to the girls students in starting of the year and complains regarding the stipend amount need to be solved immediately so that Head teachers and girls students do not face any disturbances in teaching and learning process.

06- Head teachers should arrange educational awareness programs for parents of girls' students, in which high authorities of education department should deliver motivational and fruitful speeches to encourage the communities for girls' education

07- Create more job opportunities for female for girls' schools so that after completing education they could serve their society. 


\section{References}

Bank, W. "Donor appraisal and endorsement report: National strategy for education development of the Republic of Tajikistan (2006-2015)." 2005.

Bilqees, F. and Saqib, N.U. "Drop-out rates and inter-school movements: Evidence from panel data", Pakistan Institute of Development, Islamabad, Pakistan. ." 2004.

Chadzuka, E. T. "Primary Schools' Dropout Rate in Mutare District, Zimbabwe. Department of Educational Studies, Tshwane University of Technology. ." 2008.

Dollar, D, A. "Gender Inequality, Income, and Growth: Are Good Times Good For Women?" Policy Research Report on Gender and Development, Working Paper Series 1, World Bank." 1999.

GoV, and MoE. "Pakistan, country report, education for all, mid decates assessment. islamabad: government of pakistan, ministry of education." 2008.

Hahna, Youjin. 2015.

Herz, B. K. "Letting girls learn: promising approaches in primary and secondary Education." 1991.

Hussain, S. "Secondary School Girls' Stipend Program, Impact On Female Status And Communities Economic Needs:A Qualitative Analysis." 2016.

Jafred, Muyaka. "Community Environment and Education of Girls: The Case of Communities in Marsabit County, Kenya." Universal Journal of Educational Research 6, no. 3 (2018): 430-439.

Kearney, A. "PROGRESS REPORT 2013-2015 Results for children in Pakistan, UNICEF Representative in Pakistan,islmabad." 2015.

MDG. "Bangladesh country paper ." 2012.

Naveed,, Sumbal. "The importance of educating girls in the Newly Merged Districts of Khyber Pakhtunkhwa, Pakistan ." ECHIDNA GLOBAL SCHOLARS PROGRAM POLICY PAPER , 2018. 
Pakistan, A, K. "PROGRESS REPORT 2013-2015 Results for children in Pakistan. islmabad: UNICEF." 2015.

Shahdur, R, K, M. "Subsidy to Promote Girls' Secondary Education: The Female Stipend Program in Bangladesh. International Rice Research Institute and Chiba University , 24." 2003.

Simeen. "Female secondary school stipend programme in Bangladesh backgroung paper for the education for all global monitoring report 2003/4 gender and education for all: The leap to equility. UNESCO." 2003.

Smyth, l, B. "Girls' Education, Stipend Programs and the Effects on Younger Siblings' Education." 2012.

Sperling., G, B. "What works in girls education: Evidence and politics from the developing world. New York . Council on Foreign Relations." 2004.

Webpage. "Sindh Government providing stipend to girls from class VI to X. ." 2019.

Youjin Hahna, A, I, S. "Education, Marriage and Fertility: Long-Term Evidence from a Female Stipend Program in Bangladesh." 2015. 